(4)

\title{
Impact of Economic Status on the Consumption Pattern of TV by School Children of District Vehari
}

\author{
${ }^{\mathrm{a} S a m i a}$ Manzoor, ${ }^{\mathrm{a}}$ Aasima Safdar, ${ }^{\mathrm{b}}$ Sobia Shareef \\ ${ }^{a}$ Assistant Professor of Communication Studies, Bahauddin Zakariya University, Multan, Pakistan \\ ${ }^{\mathrm{b}}$ M. Phil Student of Communication Studies, Bahauddin Zakariya University, Multan, Pakistan
}

\begin{tabular}{ll}
\hline ARTICLE DETAILS & ABSTRACT \\
\hline $\begin{array}{l}\text { History: } \\
\text { Accepted } 16 \text { March } 2020\end{array}$ & $\begin{array}{l}\text { Probing the effects of mass media on viewers has always remained a } \\
\text { Available Online } 31 \text { March } 2020\end{array}$ \\
& $\begin{array}{l}\text { topic of interest for the researchers. This specific study is based on the } \\
\text { going children in relation with their demographics. As District Vehari is }\end{array}$ \\
\hline Keywords: & an economically poor district of Punjab (Pakistan). So the present study \\
Economic status, TV viewing, & intended to evaluate the consumption pattern of TV of school going \\
Consumption patterns, & children of an economically weaker city. The sample comprised of 420 \\
Entertainment, Gratification & school-going children. A survey questionnaire was developed to collect \\
& the required information. Qualitative information was also gathered \\
JEL Classification: & from the parents of the students to gauge their economic status. \\
A10, E21, L82 & Findings of the study revealed that the reason to spend this much time \\
& on TV viewing is the economic condition of families. Parents cannot \\
afford personal gadgets for their kids so children are bound to watch TV. & However TV viewing varied with the individual differences of the \\
DOI: 10.47067/reads.v6i1.180 & students i.e. age, and gender etc.
\end{tabular}

(C) 2020 The authors. Published by SPCRD Global Publishing. This is an open access article under the Creative Commons Attribution-

NonCommercial 4.0

Corresponding author's email address: samia.manzoor@bzu.edu.pk

\section{Introduction}

Mass media plays a central role as a source of both information and entertainment for people around the world. Because of its audio-visual universality and simulative power, TV is considered very popular as a form of communication even in the 21st century when media technologies have become essential part of children's life (Jamieson \& Campbell, 2000). TV is an important element in developing the relationship between media and society as it plays the role of a window to see the outer world (Gerges, 2003). When it comes to the socialization of children, TV has been the best tool since its advent in mid-19oos. However, the parental attitude towards TV determines the extent of exposure of their children to this medium (Katz, Haas, Gurevitch, 1973).

From 1970 s to 9os, the technological advancements caused substantial changes in consumption patterns of TV and the content broadcasted in programs (Samuel, 2017). This change somehow affected the attitude of people towards TV shows and their behaviors in real life. As Marshal McLuhan said 
'medium is the message', a number of new trends were introduced as the consequence of this change in technology (Rubin, 1983). Invention of cable television and interactive media is a more advanced step offering the viewer's more choice and diversity in programs and content (Sinclair, Jacka, Cunningham, 2000). However with the advent of information technology elders as well as children have moved away from TV. But some people argue that TV still occupies a unique place in our lives. TV viewing is somehow related with the economic status of the people. In a country like Pakistan children are dependent on their parents for any commodity due to economic restrains. But she is moving towards technological advancement on a fast pace. However the area of Southern Punjab is still considered economically vulnerable. District Vehari was selected for data collection in the present research because it is best suitable as an example of a general type of town of South Punjab.

The present research not only focuses on the importance of the economic status of parents on the consumption of TV but it also shed light on the awareness level of parents about the gadgets available to kids as well as parental control on the usage of different gadgets by their children. The results of the present research will enable us to estimate the relationship of economic status with the consumption pattern of TV of small town children. Moreover this research will enable the stakeholders of TV programming to take initiatives to produce programs that will help to better educate the people of such towns in Pakistan, who are not only economically weak but also have less social knowledge.

\section{Literature Review}

There have been several studies conducted to explore the impact of different variables on TV viewing habits of youngsters. The researchers investigated the effects of gender, age, interests, audience attentions, knowledge and many other variables. As Palmgreen and Rayburn (1978) studied discrepancy approach and analyzed the exposure of audience to TV within the context of Uses and Gratifications theory. Objective of the study was to compare the level of gratification people expected from TV viewing and the level of gratification they actually received from it. Results indicated that model effectively supported the level of gratification expected and received for those who made their own decisions for viewing while there was difference in the level of gratification expected and received for those who let others to make viewing decisions.

Likewise, Rubin and Perse (1987) evaluated audience activity related to news gratifications received from TV viewing. Researchers developed hypothesis that news viewing was related to audience intentions, selection and involvement in the local news. Findings of the study supported the presumed hypothesis that audience activity is one of the most important variables in media usage and its effects on audience. Lin (1993) modeled the process of gratification and entertainment seeking through Television viewing. The main objective of the study was to examine the major motives to watch TV, activities in which people engage after TV viewing and lastly the satisfaction they receive from it. Findings of the study supported this assumption and however, the researchers suggested a revised theoretical model for the future research.

However, Harper-Gilmore (1994) examined the relationship between Television and Elementary school-going children. The results of the study showed that parents' involvement in TV viewing influenced the impact of TV on children and thus this dimension needed more study. Vincent \& Basil (1997) conducted research on college students concerning gratifications received from news, their media usage and their knowledge on current events. The main purpose of the study was to compare the consumption patterns of news usage for gratification by the college students in contrast with traditional functions of news. Findings of the research revealed that surveillance level was increased with the age and year in college increased. Students who consumed news for this purpose used all types of media 
while for entertainment students only viewed TV. On the other hand, Ruggiero (200o) explained the uses and gratification approach within the context of 21st century. He took interactivity, demassification, hypertextuality and asynchroneity as the variables for the study.

Schmitt, Wolf and Anderson (2003) inquired about the variations in viewing behaviors of children and adolescents during TV programs and during commercials. The findings of their study showed that social interaction was the main activity followed by playing games by the children, reading books for the adults and doing domestic chores for females. Moreover, researchers concluded that people were mainly engaged in activities during the programs which were less attractive or were of less interest for them like commercials etc. Utter, Scragg, Schaaf (2005) investigated the linkage between consumption pattern of commonly advertised food products and TV viewing and effect on children and young people of New Zealand. Core objective of the research was to examine the association between the time spent on watching TV and dietary behaviors of children and young people. Researchers concluded that when other factors like age, gender, ethnicity, physical activity and socio-economic status etc. were controlled, duration of the TV viewing affected the dietary behaviors of the children and young i.e. chances of obesity increased with increase in time spent watching TV.

Ebersole and Woods (2007) scrutinized the motivations of audience to watch reality TV in the uses and gratifications scenario. Researchers presumed five main influential factors i.e. entertainment, time pass, mood changing, personal identification for the real characters, and mediated participation. Results indicated that due to interactive nature of the television, audience identified the real characters which play the important role in attraction of the audience towards reality television and programming. Steffen, Fulton and Labarthe (2009) scrutinized the relationship between obesity in children and adults in relation with their TV viewing patterns and obesity in parents. Multi-variate regression analysis was employed to test the inter-relationship among the variables. Findings of the study evidently indicated the effect of both genetic and environmental linkage on children's weight. Overall, the researchers studied the impacts of motivation, environmental linkages, ethnicity, physical activity, behavior of children, age groups and psychological factors etc. It was noted that there were few studied explored the impact of socio-economic status on the TV viewing habits of children. The present study filled this gap and studied the impact of economic status on TV viewing habits of youngsters through quantitative and qualitative approaches.

\subsection{Uses and gratification}

Uses and gratification approach is utilized as theoretical framework for the study. Prime concern of this theory is to examine what people do to media instead of what media does to people (Blumler, 1979). This theory was developed by Elihu Katz, J. G. Blumler, and Michael Gurevitch in 1974. It is very important to analyze the gratification received by watching TV before its effects are analyzed (Katz, Blumler, Gurevitch, 1973). Some of these are listed as distraction, personal relationships, surveillance, and personal gain. According to these researchers TV viewing also gratifies five main needs of audience i.e. Intellectual, Emotional, Personal, Social and Tension Release.

With the advent of new technologies Robinson (1972), Winick (1988) and Tannenbaum (2014) discussed functions of TV. According to the researchers there are three main widely accepted functions of watching television by children, i.e. entertainment, information and social utility. However under the domain of Uses and Gratification theory some of the negative effects of TV have also been discussed by Katz, Blumler, Gurevitch (1974); and Liebert \& Sprafkin (1988). According to these researchers some of the negative effects of TV are physical effects, emotional effects, cognitive effects, behavioral effects. 


\subsection{Research Questions and Hypotheses}

RQ1 Do children TV viewing pattern differ during weekdays and weekends?

H1.1: It is more likely that duration of viewing TV by children on weekdays and weekends will be significantly different.

RQ2 What is the effect of demography on children's TV viewing?

H2.1: It is more likely that a strong relationship exists between gender and TV viewing of children.

H2.2: It is more likely that a strong relationship exists between age and TV viewing of children.

RQ3 What is the greatest gratification that children sought from TV?

H3.1: It is more likely strong relationship exist between gratification sought by children from TV and their age.

H3.2: It is more likely that strong relationship exist between gratification sought by children from TV and their gender.

RQ4 What is the economic status of parents of school going children of Vehari?

RQ5 What is the opinion of parents regarding the control on children use of gadgets?

RQ6 How the economic status of parents is related with the awareness and control of parents their children's gadget use?

\section{Method}

Mix mythology has been adopted for data collection; quantitative as well as qualitative methods are used. Survey technique has been used for the collection of data. Through this survey data has been collected from students regarding their TV consumption, preferences, gratifications etc. Multiple choice questions mainly constituted the survey. Moreover each child's parents were interviewed personally by the researchers to know about the economic status of the family, knowledge of parents about the gadgets and their control over children's gadget use.

\subsection{Population and sampling}

Acknowledging the requirements of the study, population of this research is comprised of all the school going children of District Vehari especially class 1st to 1oth grade students (both govt. and private sector schools are included). 420 children (210 from each gender) have been selected through stratified sampling technique. schools have been divided in to two strata i.e. private schools and government schools. Out of this initial strata 10 government ( 5 girls and 5 boys schools) and 5 private (co-education) schools have been chosen from district Vehari. Students of these schools have been further divided into two groups' boys and girls, which then sub-divided into three categories on the basis of, age i.e. children (4-8), adolescents (9-12) and adults (13-17).

\section{Findings}

\subsection{Children TV viewing pattern during weekdays and weekends}

H1: It is more likely that duration of viewing TV by children on weekdays and weekends will be significantly different.

Table 1 Relationship between children's duration of watching TV on schooldays and weekends

\begin{tabular}{|c|c|c|c|}
\hline \multirow{2}{*}{ No. } & Children's duration of watching TV on school days and weekends \\
\cline { 2 - 4 } & Duration & School Days & Weekends \\
\hline 1 & Less than an hour & 33 & 9 \\
\hline 2 & One hour & 100 & 32 \\
\hline 3 & Two hours & 153 & 99 \\
\hline 4 & More than two hours & 74 & 127 \\
\hline
\end{tabular}


Review of Economics and Development Studies, Vol. 6 (1) 2020,

\begin{tabular}{|c|c|c|c|}
\hline 5 & Do not Know & 53 & 92 \\
\hline 6 & $\begin{array}{c}\text { Do not know because TV remained turned } \\
\text { on all the time }\end{array}$ & 7 & 61 \\
\hline & Total & 420 & 420 \\
\hline
\end{tabular}

Chi square value $=127.663, \mathrm{P}$-Value $=0.000$

Above table is the cross-tabulation between the children duration of watching TV on school days and weekends. Thus, chi-square test signifies that p-value is 0.000 which means that results are significant for the relationship between both variables, so this hypothesis is accepted.

\subsection{Effect of demography on children's TV viewing}

H2.1: It is more likely that a strong relationship exist between gender and TV viewing of children.

Table 2 Relationship between gender and TV viewing of children

\begin{tabular}{|c|c|c|c|c|c|c|c|c|c|c|c|c|c|}
\hline \multirow[t]{2}{*}{ Gender } & \multicolumn{2}{|c|}{ Less than an hour } & \multicolumn{2}{|c|}{ One hour } & \multicolumn{2}{|c|}{ Two hours } & \multicolumn{2}{|c|}{ More than 2 hours } & \multicolumn{2}{|c|}{ Do not know } & \multicolumn{2}{|c|}{$\begin{array}{l}\text { Do not know } \\
\text { because TV } \\
\text { remained turned } \\
\text { on all the time }\end{array}$} & \multirow[b]{2}{*}{ Total } \\
\hline & $\begin{array}{c}\text { School } \\
\text { days }\end{array}$ & Weekends & $\begin{array}{c}\text { School } \\
\text { days }\end{array}$ & Weekends & $\begin{array}{c}\text { School } \\
\text { days }\end{array}$ & Weekends & $\begin{array}{c}\text { School } \\
\text { days }\end{array}$ & Weekends & $\begin{array}{c}\text { School } \\
\text { days }\end{array}$ & Weekends & $\begin{array}{c}\text { School } \\
\text { days }\end{array}$ & Weekends & \\
\hline Male & 14 & 2 & 50 & 13 & 78 & 55 & 41 & 61 & 24 & 54 & 3 & 25 & 420 \\
\hline Female & 19 & 7 & 50 & 19 & 75 & 44 & 33 & 66 & 29 & 38 & 4 & 36 & 420 \\
\hline Total & 33 & 9 & 100 & 32 & 153 & 99 & 74 & 127 & 53 & 92 & 7 & 60 & 840 \\
\hline
\end{tabular}

Chi square value $=6.428, \mathrm{P}-$ Value $=0.267$

This table is the cross-tabulation between the gender of children and duration of watching TV on weekdays and weekends. Thus, chi-square test signifies that p-value is 0.267 which means that results are non-significant for the relationship between both variables, so this hypothesis is not accepted.

H2.2: It is more likely that a strong relationship exist between age and TV viewing of children.

Table 3 Relationship between age and TV viewing of children

\begin{tabular}{|c|c|c|c|c|c|c|c|}
\hline Age & \multicolumn{2}{|c|}{$4-8$} & \multicolumn{2}{|c|}{ 9-12 } & \multicolumn{2}{|c|}{$13-17$} & \\
\hline $\begin{array}{l}\text { TV viewing of } \\
\text { children }\end{array}$ & $\begin{array}{c}\text { School } \\
\text { days }\end{array}$ & Weekends & $\begin{array}{c}\text { School } \\
\text { days }\end{array}$ & Weekends & $\begin{array}{c}\text { School } \\
\text { days }\end{array}$ & Weekends & Total \\
\hline $\begin{array}{c}\text { Less than an } \\
\text { hour }\end{array}$ & 13 & 1 & 8 & 4 & 12 & 4 & 42 \\
\hline One hour & 55 & 16 & 27 & 8 & 18 & 8 & 132 \\
\hline Two hours & 45 & 47 & 58 & 24 & 50 & 28 & 252 \\
\hline $\begin{array}{c}\text { More than two } \\
\text { hours }\end{array}$ & 15 & 47 & 23 & 44 & 36 & 36 & 201 \\
\hline Do not know & 12 & 20 & 21 & 43 & 20 & 29 & 145 \\
\hline $\begin{array}{l}\text { Do not know } \\
\text { because TV } \\
\text { remained } \\
\text { turned on all } \\
\text { the time }\end{array}$ & $\mathrm{O}$ & 9 & 3 & 17 & 4 & 35 & 68 \\
\hline Total & 140 & 140 & 140 & 140 & 140 & 140 & 840 \\
\hline
\end{tabular}

Chi square value $=119.266$, P-Value $=0.000$

Above table is the cross-tabulation between the age of children and duration of TV viewing on 
weekdays and weekends. Chi-square test signifies that p-value is 0.000 which means that results are significant for the relationship between both variables, so this hypothesis is accepted.

\subsection{Reasons to watch TV}

H3.1: It is more likely that strong relationship exist between gratification sought by children from TV and their age.

Table 4 Relationship between age and reasons of watching TV

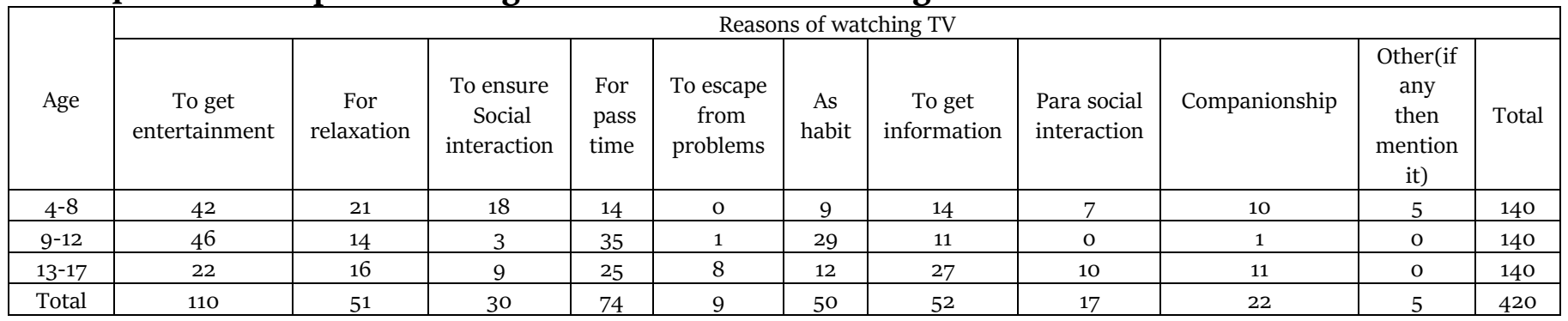

Chi-Square $=97.642$, P-Value $=0.000$

Cross-tabulation between the age of the children and the reason why children watch TV is illustrated in above table. Three categories were developed in age category as 4-8, 9-12 and 13-7. Reason to watch TV was divided into ten categories i.e. entertainment, for relaxation, to ensure social interaction, for pass time to escape from problems, as habit, to get information, for Para- social interaction, for companionship, and other. The, chi-square test signifies that p-value is o.ooo which means that results are significant for the relationship between both variables, so this hypothesis is accepted.

H3.2: It is more likely that strong relationship exist between gratification sought by children from TV and their gender.

Table 4 Relationship between gender and reasons of watching TV

\begin{tabular}{|c|c|c|c|c|c|c|c|c|c|c|c|}
\hline \multirow[b]{2}{*}{ Gender } & \multicolumn{11}{|c|}{ Reasons of watching TV } \\
\hline & $\begin{array}{c}\text { To get } \\
\text { entertainment }\end{array}$ & $\begin{array}{l}\text { For } \\
\text { relaxation }\end{array}$ & $\begin{array}{l}\text { To ensure } \\
\text { social } \\
\text { interaction }\end{array}$ & $\begin{array}{l}\text { For } \\
\text { pass } \\
\text { time }\end{array}$ & $\begin{array}{l}\text { To escape } \\
\text { from } \\
\text { problems }\end{array}$ & $\begin{array}{c}\text { As } \\
\text { habit }\end{array}$ & $\begin{array}{l}\text { To get } \\
\text { information }\end{array}$ & $\begin{array}{l}\text { Para } \\
\text { social } \\
\text { interaction }\end{array}$ & Companionship & $\begin{array}{l}\text { Other(if } \\
\text { any } \\
\text { then } \\
\text { mention } \\
\text { it) }\end{array}$ & Total \\
\hline Male & 60 & 29 & 15 & 32 & 8 & 23 & 23 & 9 & 7 & 4 & 210 \\
\hline Female & 50 & 22 & 15 & 42 & 1 & 27 & 29 & 8 & 15 & 1 & 210 \\
\hline Total & 110 & 51 & 30 & 74 & 9 & 50 & 52 & 17 & 22 & 5 & 420 \\
\hline
\end{tabular}

Chi-Square $=16.586, \mathrm{P}-$ Value $=0.121$

Above table is the demonstration of cross-tab between the gender of the children and the reason why children watch TV. Two sections were developed in gender category as male and female. Reason to watch TV was divided into ten categories i.e. entertainment, for relaxation, to ensure social interaction, for pass time to escape from problems, as habit, to get information, for Para- social interaction, for companionship, and other. The, chi-square test signifies that $\mathrm{p}$-value is 0.121 which means that results are non-significant for the relationship between both variables, so this hypothesis is not accepted.

\section{Qualitative Analysis}

An interview was conducted with the parents of the children; the reason of this interview was to estimate the economic status of the respondents and to gauge economic status wise control of TV 
viewing and gadgets use of the children. The following themes emerged out of the answers of the parents:

\subsection{Economic Status}

Some of the parents were initially reluctant to talk about their economic situation but when reassured that their views will be kept confidential shared their economic situation. In most household only one male was the only earning hand, mostly doing a blue collar job or managing the finances through agriculture owning a small piece of land. On the basis of the responses of parents, three categories of economic status emerged.

\subsubsection{Middle class}

Most of the parents told that they belong to the middle class. As they had one family car, a house where every member of the family was not entitled to a separate room and the monthly income was though sufficient to make their ends meet but not enough to afford luxuries.

\subsubsection{Lower Middle class}

A few number of the parents told that it becomes difficult sometimes for them to provide all needs to the family in the limited household budget however they also categorized themselves as middle class.

\subsubsection{Upper Middle class}

A little category of parents classified themselves as upper middle class. As they had sufficient savings, personal home and secure future plans. So out of these findings it was resulted that most of the households of Vehari have middle class economic status with slight variations.

\subsection{Knowledge about Gadgets}

\subsubsection{Extremely Poor Knowledge}

Most of the parents told that they don't hold sufficient knowledge about modern day gadgets available to children. Though many of them knew about video games but they were unaware about the contemporary video games and other technological items available to them. Mothers were more naïve about this whereas fathers were comparatively more knowledgeable.

\subsubsection{Moderate Knowledge}

Some parents shared that their children use their mobiles and some others told that they have given their children a tab for their personal use. Majority of the parents when asked do their kids have their personal gadgets? Their answer was no. either the children were using their parent's mobiles in their free time or they were given a single tablet or mobile which they were sharing with their siblings. Affordability was the prime factor for not having personal gadgets. Most of the parents told that they do not have the purchasing power to buy some hi tech gadget to their children. This comprises of the vastest category of parents.

\subsubsection{Sufficient Knowledge}

Very few parents were knowledgeable about Xbox, PlayStation, and related gear. Only a couple of parents admitted that they have provided their kids with personal gadgets or they are enjoying some hi tech gear. These parents were the scarcest. Although they were knowledge about modern day gadgets but affordability was a major factor for them.

\subsection{Parents Control on Children Media Use}


Almost all the parents said that they control their kid's media use. But how much they were controlling and how much they were successful in this control had varying responses.

\subsubsection{No Control}

Some of the fathers said that they don't want to control their kid's leisure time when the kids are doing great at school. But almost all the mothers' said that they have given schedule to their kids to use any kind of gadget including TV. But when question about the strictness in following the strictness using gadgets mostly parents admitted that they are not very strict with it. It was also observed that upper middle class mothers were not very much concerned with what and for how long their kids' are using TV or any other device,

\subsubsection{Moderate Control}

Usually parents of middle school children were more concerned about the time and content control of children. Middle class parents were most concerned about this issue. Almost all the parents belonging to middle class told that their children either use the mobile of parents or are enjoying a single gadget that is meant for all the siblings so they cannot use it for longer periods of time.

\section{Discussion}

After the decades of research in the field of mass media, Uses and gratification approach is now considered as the most influential theoretical foundation for the researchers. The present research is unique because not only the children's consumption pattern of TV were identified but it was also explored that how does the economic situation of parents affect the consumption pattern. Keeping in mind the basics of Uses \& Gratification approach, some questions were developed by the researchers which are answered as following: A finding regarding the type of gratification TV provides to children in this study is evident from respondents' answers that for both age groups 4-8 and 9-12 entertainment was the maximum gratification while for the age group 13-17 watched TV to get information. Previous researchers like McQuail, Blumler \& Brown (1972); Rijitha (2009); Woods \& Ebesole (2007); Wincent \& Basil (1997); Palmgreen \& Rayburn (1979) approved this point while Rubin (1987) rejected it. But this study is the addition to studies which accepted it.

Moreover the durations and timings change for TV watching on schooldays and weekends because during schooldays, children have to go to school and to do homework, that's why they have less time to watch TV but on weekends they have more time but also some students like to play games (physical games) than sitting in front of TV, so the changes in pattern are slight. These reasons are argued by Mullings (2012). Harper (1992) argued that although media has significant effects but the demographics of the children in particular and psychographics in general influence the patterns of effects on viewers by media. Though the results regarding the effects of children demography (gender, age) and TV viewing preferences, which shows that there might not significant changes in viewing patterns on the basis of gender but age matters a lot, in childhood children like cartoons etc. but with the passage of time children's preferences change, girls start taking interest in dramas, movies while boys like games and action programs.

Economic status of the families plays a pivotal role in their viewing preferences. Vehari is a small district of South Punjab. Most of the families are managing their expenses within limited resources. And belong to the middle class. They do not have the resources to provide luxuries to their children. This is a main reason that children in this region are bound to spend most of their leisure time in watching TV. Moreover due to the lack of education and awareness of parent they have very limited or no control on their children's consumption of TV. These factors reveal that economic status of a 
family is very important in the gadget and TV use of their children.

\section{Conclusion}

The results of the present research show that the demography of the children considerably influences the TV viewing pattern of children, especially their age a great influence on their TV consumption. Children's interest in TV and their gadget use is very much related with their age. So this information is of utmost importance for parents. Parents need to have a control on their children regarding their TV consumption and their gadget use. Furthermore, it was found that patterns of watching TV were significantly different for school days and weekends. Subsequently, they love to watch TV during schooldays for just two hours as they have a lot of other activities like school, homework etc. but there is an interesting finding that even on weekends they watch TV just a little more than two hours because they love to play physical and computer games. Parents' economic status also played a key role in determining the consumption of different gadgets including TV. This research was conducted in an area where purchasing power of the parents was not much that is why affordability of gadgets was a major factor. Due to lack of personal gadgets children were bound to watch TV more. It was concluded that findings of this study supported the earlier work done by several researchers that demographics play important role. It opens a new dimension in the theory of uses and gratifications that children start using the medium which is available to them to gratify their needs. In a country like Pakistan TV is still a source of entertainment to most of the children living in not so developed areas. So TV channels need to produce programs to meet the needs of school going children. As special programs are not designed for children so they are bound to consume programs meant for adults and with very limited control of parents on their consumption of TV they become familiar with such topics and issues which are not suitable at their age.

\section{References}

Blumler, J. G. (1979). The role of theory in uses and gratifications studies. Communication research, 6(1), 9-36.

Ebersole, S., \& Woods, R. (2007). Motivations for viewing reality television: A uses and gratification analysis. Southwestern Mass Communication Journal, 23(1). 23-42

Gerges, F. A. (2003). Islam and Muslims in the mind of America. The Annals of the American Academy of Political and Social Science, 588(1), 73-89.

Gülay Ogelman, H., Güngör, H., Körükçü, Ö., \& Erten Sarkaya, H. (2018). Examination of the relationship between technology use of 5-6 year-old children and their social skills and social status. Early child development and care, 188(2), 168-182.

DOI: $10.1080 / 03004430.2016 .1208190$

Harper-Gilmore, S. L. (1994). Television and elementary school children, Doctoral dissertation, University of Delaware.

Jamieson, K. H. \& Campbell, K. K. (2000). The Interplay of Influence: News, Advertising, Politics, and the Mass Media. Belmont, CA: Wadsworth Pub Co.

Katz, E., Blumler, J. G., \& Gurevitch, M. (1973). Uses and gratifications research. The public opinion quarterly, 37(4), 509-523.

Katz, E., Blumler, J. G., \& Gurevitch, M. (1974). The uses and gratifications approach to mass communication. Beverly Hills, Calif.: Sage Publications. 
Katz, E., Haas, H., \& Gurevitch, M. (1973). On the use of the mass media for important things. American Sociological Review, 38, 164-181. Doi: 10.2307/2094393

Liebert, R. M., \& Sprafkin, J. (1988). The early window: Effects of television on children and youth. Pergamon Press.

Lin, C. A. (1993). Modeling the gratification-seeking process of television viewing. Human Communication Research, 20(2), 224-244.

McQuail, D, Blumler, J \& Brown, J. R. (red) (1972). Sociology of the Mass Media. UK: Penguin Books.

Mullings N. (2012). Inner-City High School Student's Academic Achievement and Reality Television Effect. Unpublished Doctoral Dissertation. Gonzaga University

Palmgreen, P., \& Rayburn, J. D. (1979). Uses and gratifications and exposure to public television: A discrepancy approach. Communication Research, 6(2), 155-179. DOI: 10.1177/009365027900600203

Rijitha R, (2009) TV In the context of Uses and Gratification approach. University of Madras. Net library database.

Robinson, J. P. (1972). Toward defining the functions of television. Television and social behavior, 4 , 568-603.

Rubin, A. M. (1983). Television uses and gratifications: The interactions of viewing patterns and motivations. Journal of Broadcasting \& Electronic Media, 27(1), 37-51.

Rubin, A. M., \& Perse, E. M. (1987). Audience activity and television news gratifications. Communication research, 14(1), 58-84.

Ruggiero, T. E. (2000). Uses and gratifications theory in the 21st century. Mass communication \& society, 3(1), 3-37.

Samuel, M. (2017). Time Wasting and the Contemporary Television-Viewing Experience. University of Toronto Quarterly, 86(4), 78-89. https://www.utpjournals.press/doi/pdf/10.3138/utq.86.4.78

Schmitt, K. L., Woolf, K. D., \& Anderson, D. R. (2003). Viewing the viewers: Viewing behaviors by children and adults during television programs and commercials. Journal of Communication, 53(2), 265-281.

Sinclair, J., Jacka, E., \& Cunningham, S. (1996). New patterns in global television: Peripheral vision. Oxford: Oxford University Press.

Steffen, L. M., Dai, S., Fulton, J. E., \& Labarthe, D. R. (2009). Overweight in children and adolescents associated with TV viewing and parental weight: Project HeartBeat!. American journal of preventive medicine, $37(1)$, S50-S55.

Tannenbaum, P. H. (Ed.). (2014). The entertainment functions of television. Psychology Press.

Utter, J., Scragg, R., \& Schaaf, D. (2006). Associations between television viewing and consumption of commonly advertised foods among New Zealand children and young adolescents. Public health nutrition, 9(05), 606-612.

Vincent, R. C., \& Basil, M. D. (1997). College students' news gratifications, media use, and current events knowledge. Journal of Broadcasting \& Electronic Media, 41(3), 380-392.

Winick, C. (1988). The functions of television: life without the big box. In Oskamp, S. (ed.), Television as a Social Issue. Sage, Beverly Hills, CA, pp. 217-238. 